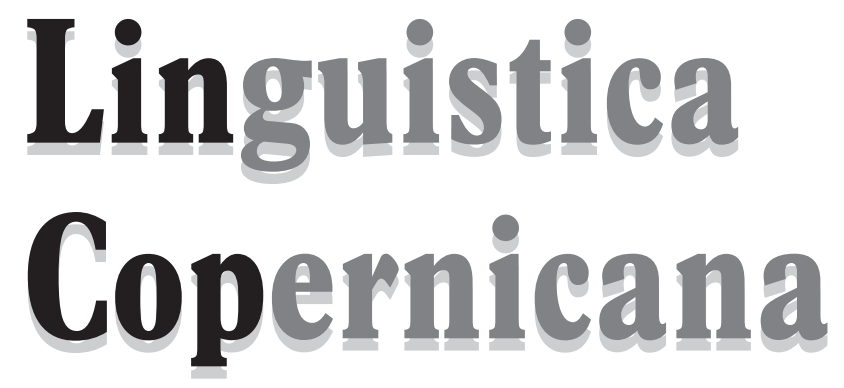

$1(7) / 2012$

WYDAWNICTWO NAUKOWE
UNIWERSytetu MIKOLAJa KOPERNIKA 
REDAKTOR NACZELnY: Maciej Grochowski

Rada Redakcyjna: Ireneusz Bobrowski (Kraków), Andrzej Bogusławski (Warszawa), Gerd Hentschel (Niemcy, Oldenburg), Axel Holvoet (Litwa, Wilno), Krystyna Kleszczowa (Katowice), Roman Laskowski (Kraków), Jarmila Panevová (Czechy, Praha), Jens Nørgård-Sørensen (Dania, Kopenhaga), Zuzanna Topolińska (Macedonia, Skopje), Daniel Weiss (Szwajcaria, Zurich), Anna Wierzbicka (Australia, Canberra)

Kole gi u m R e D K C Y J e: Maciej Grochowski, Krystyna Kallas, Irena Sawicka, Piotr Stalmaszczyk

S E K R ETA R Z R E D A K C I: Iwona Kaproń-Charzyńska

A D R E S R E D A K C J I: Instytut Języka Polskiego UMK, 87-100 Toruń, ul. Fosa Staromiejska 3, e-mail: lincop@umk.pl,www.linguistica.umk.pl

OKŁ A D K A: Monika Pest

(C) Copyright by Wydawnictwo Naukowe Uniwersytetu Mikołaja Kopernika

Toruń 2012

ISSN 2080-1068

Wersją pierwotną (referencyjną) czasopisma jest wersja papierowa.

WYDAWNICTWO NAUKOWE UNIWERSYTETU MIKOEAJA KOPERNIKA

Redakcja: ul. Gagarina 5, 87-100 Toruń

tel. (56) 6114295 , tel./fax 6114705

e-mail: wydawnictwo@umk.pl

Dystrybucja: ul. Reja 25, 87-100 Toruń

tel./fax (56) 61142 38, e-mail: books@umk.pl

www.wydawnictwoumk.pl

Druk: Wydawnictwo Naukowe UMK 
Izabela Duraj-Nowosielska

\section{Kilka uwag o wpływie przycisku zdaniowego na interpretację przysłówków-modyfikatorów intencjonalności (na przykładzie niechcacy, przypadkiem)}

Słow a klucze: akcent zdaniowy, czynności, działania, intencjonalność, niechcacy, przycisk zdaniowy, przypadek, przypadkiem, przysłówek, struktura tematyczno-rematyczna

Do przysłówków określanych tu mianem modyfikatorów intencjonalności działania zaliczam wyrażenia takie jak - z jednej strony - mimowolnie, niechcacy, nieświadomie itp. (przysłówki „nieintencjonalne”), a z drugiej celowo, specjalnie, świadomie itd. (przysłówki ,intencjonalne”). Słowo przypadkiem, wymienione w tytule, wprawdzie nie bez powodu może być podejrzewane o to, że ma szersze znaczenie, nieodwołujące się do pojęć z dziedziny agentywności (por. z prac semantycznych: Grochowski 2009, Bogusławski 2009), jednak, jak spróbuję pokazać, na ogół zachowuje się ono jak typowy modyfikator intencjonalności i może być interpretowany analogicznie do innych wyrażeń tego rodzaju. Warto w każdym razie rozważyć ewentualność jego systemowego odniesienia do agensa i agentywności, także w zdaniach pozbawionych takiego odniesienia na powierzchni. O tym problemie częściowo będzie mowa poniżej, sygnalizowałam go też w: Duraj-Nowosielska 2013 
i dalej rozwijam w artykule pt. $O$ (tajemniczej) roli intencjonalnego działania $w$ zdaniach z przysłówkiem 'przypadkiem' (Duraj-Nowosielska w druku [b]).

Wszystkie wymienione tu jednostki są wyrażeniami zasadniczo rematycznymi, tzn. w odróżnieniu od wyrażeń „inherentnie tematycznych” (por. Bogusławski 1999) mogą być one nosicielami podstawowego akcentu zdaniowego: [ktoś coś zrobił] niechcqcy, nieświadomie - [ktoś coś zrobit] celowo, świadomie. A jednak, jak się zaraz przekonamy, w strukturze akcentowej zdań z przysłówkami ,intencjonalnymi” i z przysłówkami ,nieintencjonalnymi” daje się zauważyć pewna istotna asymetria, która będzie się oczywiście przekładała na ich układ tematyczno-rematyczny, a w konsekwencji-na semantyczny opis tych wyrażeń. W pierwszej części przedstawię pokrótce problem owej asymetrii, w drugiej natomiast pokażę na kilku przykładach, jak interpretacja interesujących nas przysłówków może zależeć od rozkładu akcentów w zdaniu. Zaznaczam, że w tej krótkiej rozprawce sygnalizuję jedynie problem i nie próbuję dać ostatecznej odpowiedzi na pytanie, do jakiego stopnia te rozbieżności są kwestią różnic systemowych, a do jakiego dają się wytłumaczyć w inny sposób.

1. Mówiąc o strukturze tematyczno-rematycznej zdań z tytułowymi wyrażeniami, związanej z rozkładem akcentów pewnego typu, posługuję się pojęciem neutralnego układu zdania oraz neutralnej pozycji w ramach takiego układu. Pojęcia te dotyczą zdań (możliwie) izolowanych, bo tylko takie uważam za prawdziwie diagnostyczne w analizie znaczenia wyrazów wchodzących w ich skład, i wskazuja - można powiedzieć - na pierwszy, intuicyjny sposób ich odczytania. Przyjmuję, że to wszystko ma znaczenie w semantyce, tj. że nie sposób opisywać wyrażeń poza kontekstem zdaniowym: eksplikując sens danego wyrażenia, musimy się zdecydować na opis wyrażenia pozostającego $\mathrm{w}$ jak i ejś pozycji zdaniowej.

I tak, dla przysłówków „nieintencjonalnych” najbardziej naturalna wydaje się pozycja nie w ramach rematu, lecz w ramach dictum tematycznego zdania; główny akcent zdaniowy spoczywa na czasowniku (co nie znaczy, że inne konfiguracje kontekstowo nie są możliwe). Przysłówki „intencjonalne” natomiast tworzą typowo z czasownikiem remat równoległy, por.:

(1) Jan niechcący podarł gazetę. 
(2) Jan celowo podarl gazetę 1 .

Próba odwrócenia akcentów w zdaniu ,intencjonalnym” kończy się według mnie niepowodzeniem:

(2a) ? Jan celowo podarł gazetę.

Co do zdania „,nieintencjonalnego”, wydaje się, że taka akcentuacja jest dopuszczalna, aczkolwiek będzie wtórna wobec uznanej tutaj za podstawową, z przysłówkiem tematycznym; w zdaniu:

\section{(1a) Jan niechcący podarl gazetę}

podkreśla się (opcjonalnie) „nieintencjonalność”, przy czym nie chodzi tu o akcent kontrastywny, por. z:

(1b) Jan podarł gazetę NIECHCĄCY, a nie CELOWO,

ani o operację eksplicytnego wyboru tematu (zob. o niej Bogusławski 1977), por.:

(1c) Jan podarł gazetę / niechcący ( $>$ o tym, że Jan podarł gazetę, mogę powiedzieć, że zrobił to niechcący).

Tak więc zdania typu (1a) nie mają takiego statusu jak analogiczne zdania „intencjonalne”, gdzie inna akcentuacja w ogóle nie wydaje się możliwa. Por. też analogiczne:

(3) Wczoraj Józek ją nieświadomie oszukal.

[(3a) Wczoraj Józek ją nieświadomie oszukat.]

(4) Wczoraj Józek ją świadomie oszukat.

(4a) ? Wczoraj Józek ją świadomie oszukal.

1 Podkreślam, że zdania te należy czytać możliwie bez kontekstu, gdyż odwołanie się do wyjaśnień kontekstowych może zmieniać rozkład akcentów. Kwestie teoretyczne rozważane w p. 1 rozwijam też w pracy: Duraj-Nowosielska (w druku [a]). 
(5) (Wtedy) Janek mimowolnie spojrzał w stronę Basi.

[(5a) (Wtedy) Janek mimowolnie spojrzał w stronę Basi.]

(6) (Wtedy) Janek specjalnie spojrzal w stronę Basi.

(6a) ? (Wtedy) Janek specjalnie spojrzal w stronę Basi.

(7) Przejeżdżający obok kierowca nieumyślnie ochlapał przechodniów.

[(7a) Przejeżdżający obok kierowca nieumyślnie ochlapal przechodniów.]

(8) Przejeżdżający obok kierowca umyślnie ochlapał przechodniów.

(8a) ? Przejeżdżający obok kierowca umyślnie ochlapał przechodniów ${ }^{2}$.

Przykłady te pokazują, że symetryczne traktowanie przysłówków ,,intencjonalnych” i ,nieintencjonalnych”, tj. automatyczne analizowanie ich jako równorzędnych rematów $\mathrm{z}$ tematami $\mathrm{w}$ postaci określonych struktur predykatowo-argumentowych, jest błędne. Analiza semantyczna nie idzie tu zatem w ślad za strukturą składniową, sugerującą, że przysłówki „intencjonalne” i „nieintencjonalne” powinno się traktować na równi jako dwa analogiczne typy określeń predykatów czasownikowych: nigdy nie jest tak, że kiedy ktoś coś robi, może to robić np. „specjalnie” równie dobrze jak „niechcący” (o czym pisał swego czasu John Austin, 1977).

Warto oczywiście postawić pytanie, skąd się bierze ta rozbieżność.

Moja ogólna propozycja interpretacyjna jest tu taka, że dla podmiotów osobowych najbardziej właściwe (i w jakiś sposób spodziewane po wystąpieniu podmiotu osobowego) jest robienie czegoś ,intencjonalnie”, a mimo to pod groźbą regresu ,intencjonalność” nie może być niezależnym określeniem owych „akcji” (tak to ujmował we wspomnianej, klasycznej już pracy Austin 1977). Można powiedzieć, że n a uw a gę zasługuje dopiero sytuacja, kiedy x robił $\mathrm{p}$, ale przy okazji zrobił jakieś inne $\mathrm{q}-\mathrm{i}$ dopiero taką sytuację opatrujemy komentarzem językowym, tj. przysłówkiem z grupy wyrażeń „nieintencjonalnych”, np. robił p, ale niechcący zrobił q. Ni e b ęd z i e to jednakże przysłówek w pozycji rematycznej: ta pozycja jest normalnie zarezerwowana dla osiągniętego skutku, przysłówek wejdzie nato-

2 Powtórzę, że żadne z tych zdań nie dotyczy operacji eksplicytnego wyboru tematu, w których np. o tym, że Józek kogoś oszukał, mówi się, że zrobił to świadomie / nieświadomie, a które wiążą się z jeszcze innym, wtórnym względem podstawowego konturem intonacyjnym. 
miast do dictum tematycznego, określając warunki, w jakich doszło do orzeczonego skutku q.

Natura przysłówków ,intencjonalnych” jest inna: właśnie dlatego (a nie: pomimo tego), że po podmiotach osobowych spodziewamy się ,intencjonalnego" działania, normalnie tego nie orzekamy (jest więc dokładnie odwrotnie, niż to swego czasu sugerowały analizy w ramach semantyki generatywnej, np. Talmy'ego 1976). W języku nie znajdziemy żadnego takiego neutralnego określenia, a słowo intencjonalny jest w polszczyźnie sztucznym tworem, wprawdzie użytecznym jako termin roboczy (tutaj stosuję je jako hasło wywoławcze dla pewnego typu wyrażeń), ale nic w istocie nie tłumaczącym. Przysłówki ,intencjonalne”, takie jak celowo, specjalnie, świadomie mają znacznie bogatszą semantykę niż ,intencjonalność”, do jakiej nawiązują wyrażenia działanie czy czynność, i będą zawsze orzeczone niezależnie.

2. Po tych ogólnych uwagach na temat rozkładu akcentowego (tematyczno-rematycznego) zdań z przysłówkami - modyfikatorami intencjonalności działania, przechodzę do pytania, jaki wpływ może mieć przycisk zdaniowy lub jego brak na semantykę tych wyrażeń. Mowa będzie o przysłówkach „nieintencjonalnych”, gdyż one co prawda mogą zostać w zdaniu zaakcentowane i funkcjonować w charakterze rematów, lecz w odróżnieniu od przysłówków ,intencjonalnych” - nie muszą, co więcej - t y p o w o właśnie nie są rematami (czyli wchodzą w skład dictum tematycznego).

Otwiera się tu przy okazji ciekawy problem teoretyczny, gdyż pod kątem akcentu zdaniowego trzeba przemyśleć kwestię ostatecznej eksplikacji znaczenia przysłówka: dla wyrażeń prymarnie należących do dictum zdania podstawą eksplikacji powinna być w zasadzie pozycja rematyczna, natomiast rozbieżności wynikające $\mathrm{z}$ ich przesunięcia do dictum tematycznego byłyby w jakimś sensie wtórne. Jak się jednak wydaje, przysłówków - tych przynajmniej, które nas tu interesują - nie da się w ten sposób d ob r ze opisać, bo to by wymagało kontekstu zdaniowego uznanego tu za wtórny, mianowicie nieizolowanego kontekstu $\mathrm{z}$ eksplicytnie wybranym tematem, jak w (1c). W zdaniach izolowanych przysłówki albo normalnie nie będą w ogóle nosicielami akcentu zdaniowego (,nieintencjonalne”), albo będą nosiły akcent równoległy, na równi z czasownikiem („,intencjonalne”). Stajemy zatem przed dylematem, czy lepiej byłoby „oczyścić” kontekst zdaniowy i skupić się na własnościach rematu-przysłówka, za cenę wtórności kontekstu, czy 
opisywać zdania „neutralne”, za cenę możliwego semantycznego pogmatwania jako wyniku nałożenia się pewnych wtórnych cech (wraz ze zjawiskiem presupozycji itp.) na podstawowe własności wyrażeń. To ostatnie bierze się chociażby stąd, że dla wyrażeń pozostających w dictum tematycznym trudno zastosować wprost test negacji, z tego prostego powodu, że człon przeciwstawny w tym teście będziemy przede wszystkim odnosili do rematu zdania poprzedzającego. Por. np.:

(9) *Przebiegając obok Anny, Marcin ją niechcący potrącil, chociaż przebiegając obok niej, chciał ją właśnie potrącić.

(9a) *Przebiegając obok Anny, Marcin ją potrącił niechcący, chociaż przebiegając obok niej, chciał ją właśnie potrącić.

Obydwa zdania są nieakceptowalne, jednak tylko (9a) w jasny sposób kontrastuje daną cechę semantyczną („chcieć p”); na dewiacyjność zdania (9) składa się dodatkowo szczególna niefortunność sformułowania, wynikająca $\mathrm{z}$ tego, że kontrastowana cecha $\mathrm{n}$ i e traf i a we właściwe miejsce zdania wyjściowego. W pewnych sytuacjach akceptowalność zdań będzie się z tego powodu różnić, por.:

(10) Janek niechcący stłukł ulubioną filiżankę mamy, ale udało mu się szybko ją odkupić.

(10a) ? Janek stłukł ulubioną filiżankę mamy niechcący, ale udało mu się szybko ją odkupić -

w (10a) nie rozumiemy właśnie, dlaczego odkupienie filiżanki miałoby tu kontrastować z faktem, że została ona stłuczona „niechcący”.

Mimo wszystko trzeba powiedzieć, że opis w kontekście rematycznym ma swoje wyraźne ograniczenia: być może ze zdania (1c) moglibyśmy stosunkowo łatwo wyłuskać elementy semantyczne przysłówka niechcacy, lecz nie zmieniłoby to faktu, że te elementy w tak im uw i kłan i u będą się pojawiały tylko w jednym, ściśle określonym i na pewno nie „neutralnym” typie kontekstów (zakładającym operację explicit theme selection, Bogusławski 1977). Z drugiej strony, chcąc wyjść od kontekstów neutralnych, ryzykujemy, jak powiedziałam, splątanie semantycznych własności samego przysłówka z ogólnymi cechami innych wyrażeń pozostającymi w pozycji rematycznej; 
właściwie to splątanie wydaje się wręcz nieuniknione, bo w zdaniach takich jak (1a) zawsze będzie ostatecznie mowa o tym, co ktoś zrobił.

Mając na uwadze wszystkie te teoretyczne kwestie, skupmy się poniżej na kilku przykładach rozbieżności interpretacyjnych pomiędzy przysłówkami rematyzowanymi a przysłówkami tematyzowanymi. Z podanych wyżej powodów przyjmuję, że przysłówki „nieintencjonalne” będą pokazywały swe najbardziej specyficzne właściwości w pozycji tematycznej ${ }^{3}$, niezależnie od tego, że mogą się one okazać bogatsze niż własności wyrażeń rematycznych. Jednak właśnie z tego względu jest to kwestia bardzo złożona, wykraczająca poza ramy tej niewielkiej pracy, stąd problem ewentualnych regularności związanych z przejściem od jednej pozycji do drugiej oraz samego kierunku operacji muszę pozostawić do dalszego przemyślenia.

2.1. I tak, użycie słowa niechcacy w pozycji nieakcentowanej przed orzeczeniem sugeruje, że w ocenie nadawcy musiały istnieć jakieś powody, dla których podmiot miałby unikać sytuacji w rodzaju orzeczonego $\mathrm{p}$ (w: Duraj-Nowosielska 2011, gdzie analizuję dokładniej ten przysłówek, ujmuję ten element znaczeniowy w komponencie: „można myśleć, że z pewnych powodów x nie będzie chciał p"; szczegóły jego eksplikacji zob. też w: Duraj-Nowosielska, w druku [a]). Por.:

(11) *Jan niechcący połknął guzik, choć nie miał przecież żadnego powodu, żeby nie chcieć go połykać - uwielbia połykać guziki.

(12) *Jan niechcący pomógł Marii, nie ma zresztą żadnego powodu, dla którego miałby nie chcieć jej wtedy pomóc - Maria jest jego najlepszą przyjaciółką.

Z tego powodu dziwnie brzmi zdanie:

(13) ?Jan niechcący pomógł swojej najlepszej przyjaciółce ${ }^{4}$ Vs:

${ }^{3}$ Chodzić jednak będzie cały czas o przysłówki, nie o wyrażenia z poziomu metawypowiedzeniowego. O przypadkiem metapredykatywnym jest mowa we wspomnianych pracach Grochowskiego 2009 i Bogusławskiego 2009.

${ }^{4}$ Ponieważ brak w nim bezpośredniego zaprzeczenia, oznaczone ono zostało znakiem zapytania; chodzi w nim jednak o ukryte zanegowanie tej samej cechy semantycznej. Dalej będę stosować właśnie taką podwójną notację: dla zdań uderzająco dewiacyjnych - „,", dla po prostu nieakceptowalnych - „?", które to znaki oddają moją własną 
(14) Jan niechcący pomógł swojemu największemu wrogowi.

Z drugiej strony, pozycja pod akcentem wydaje się wcale nie wprowadzać tego rodzaju ograniczenia, por.:

(15) Jan pomógł swojej przyjaciółce zupełnie niechcący; zresztą nie ma żadnego powodu, dla którego miałby nie chcieć jej pomóc - Maria jest jego najlepszą przyjaciółką.

Jeszcze jeden, podobny przykład. Zdanie:

(16) Wczoraj Janek niechcący spotkał na uniwersytecie Jankę sugeruje, że Janek wolałby Janki nie spotykać, w odróżnieniu od zdania:

(16a) Wczoraj Janek spotkał na uniwersytecie - całkiem niechcący Jankę,

które nie niesie już ze sobą takiej sugestii, przeciwnie - w takim sformułowaniu (przez swój kontrastywny wydźwięk) podsuwa, że spotkanie Janki mogło być dla Janka wręcz czymś pożądanym, być może nawet Janek wcześniej nieraz usiłował się z Janką spotkać. Por.:

(17) ? Wczoraj Janek niechcący spotkal na uniwersytecie Jankę, i bardzo się na jej widok ucieszył,

vs zupełnie poprawne:

(17a) Wczoraj Janek spotkał na uniwersytecie - całkiem niechcący Jankę, i bardzo się na jej widok ucieszył.

intuicję semantyczną, być może w pewnych punktach dyskusyjną. Warte dyskusji są też oczywiście (czy może przede wszystkim) same podstawy rozróżnienia na zdania z gwiazdką i ze znakiem zapytania, przyznam jednak, że w tym miejscu oznaczenia te nie są stosowane na tyle precyzyjnie, bym mogła zadeklarować, o jaki dokładnie typ dewiacyjności chodzi za każdym razem. (Por. w tym kontekście Myśli o gwiazdce i o regule A. Bogusławskiego 2009.) 
Ta różnica interpretacyjna bierze się stąd, że kontekst rematyczny uwydatnia konkretny moment zdarzenia p (spotkanie Janki na uniwersytecie), wskazując na „niechcenie” podmiotu odniesione do tego konkretnego zdarzenia w tym konkretnym momencie. Przysłówek w pozycji tematycznej co prawda również ten moment eksponuje, ale oprócz tego (właśnie dzięki zajmowanej przez siebie pozycji) oddziałuje, jakby promieniuje na to, co jest związane z wszelkimi treściami tematycznymi (presuponowanymi) i co tworzy swoiste kon-teksty i pod-teksty dla treści orzekanych wprost (rematyzowanych) - w efekcie w zdaniu (16) spotkanie Janki jako takie odbierane jest jako coś niechcianego.

Trzeba jeszcze zaznaczyć, że „niechcenie” odniesione do czasownika głównego, zarówno w kontekście rematycznym, jak i tematycznym, oznacza „brak chcenia”, tj. ,x nie: chciał p” = „,nie jest tak, że x chciał p” (np. zdanie [16] mówi po prostu: nie było tak, że idąc na uniwersytet, Janek zamyślał spotkać tam Jankę); odniesione natomiast do treści tematyzowanych jest „,niechceniem” w sensie „x nie-chce p” = „,x chce nie-p”, na zasadzie ,aktywnego" niechcenia (łac. nolo), a nie „braku chcenia p”. Komponent „można myśleć, że z jakichś powodów x nie będzie chciał p” oznacza więc „można myśleć, że x będzie nie-chciał p” (= „można myśleć, że x będzie chciał nie-p”), co sugeruje „niepożądaność” p, a nie: „można myśleć, że nie będzie tak, że x będzie chciał p". To ostatnie sugerowałoby, że x mógłby nawet n i e mó c pomyśleć o p, gdy tymczasem przysłówek niechcacy - odwrotnie zakłada mo żli w oś ć pomyślenia o p (wraz z możliwością chcenia p, zob.

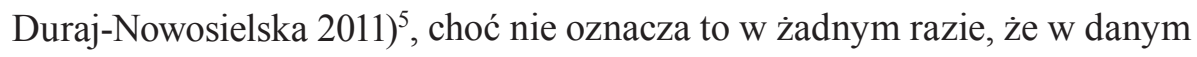
momencie x musi rzeczywiście taką ewentualność rozważać.

Powracając do przykładów (13) i (14), może być wręcz tak, że w danej sytuacji Jan usiłował pomóc Marii, lecz mu się to nie udało przy pomocy środków przez niego samego w tym celu zastosowanych, a równocześnie zaszły jakieś dodatkowe okoliczności, które sprawiły, że Jan jej ostatecznie pomógł. Tego typu sytuację można opisać je dy n i e kładąc przycisk zdaniowy na niechcacy:

5 Por. zdania z cytowanej pracy: Wychodzac ze szkoty jak co dzień o 14, tego dnia dzieci natknęty się w bramie na lwa, który uciekt z zoo. Vs: ? Wychodzac ze szkoły jak co dzień o 14, tego dnia dzieci niechcacy natknęty się w bramie na lwa, który uciekt z zoo. 
(18) Jan usiłował pomóc swojej przyjaciółce, a ostatecznie pomógł jej całkiem niechcący. Vs:

(18a) *Jan usiłował pomóc swojej przyjaciółce, a/i ostatecznie niechcący jej pomógl.

Por. również parę zdań z czasownikiem udać się:

(19) *Janowi niechcący udało się zawiązać sznurówki. Vs:

(19a) Udało mu się to zupełnie niechcący,

które ilustrują ten sam problem interpretacyjny, naturalnie dzięki implikacji mówiącej o podjęciu świadomego działania w celu p.

Kolejna właściwość semantyczna słowa niechcacy, o której chciałabym w tym miejscu wspomnieć i która nie zachowuje się przy zmianie jego pozycji z nieakcentowanej na akcentowaną, ma również związek z owym „promieniowaniem" przysłówka na tematyzowane, kontekstowo-presupozycyjne treści zdania. Jest to założenie, że podmiot n a o g ó 1 nie robi tego, na co wskazuje zdanie (w odróżnieniu od sytuacji, kiedy podmiot na ogół robi to „intencjonalnie”, a jedynie pewnego razu zdarzyło mu się to niechcący). Por.:

(20) ? Wczoraj Józek, kiedy tłumaczył Kasi lekcje, niechcący wprowadzil ją w błąd, zresztą od pewnego czasu robił to celowo za każdym razem, kiedy pomagał jej w lekcjach.

Takie zdanie jest możliwe wyłącznie z niechcacy pod akcentem, najlepiej kontrastywnym, por.:

(20a) Wprawdzie Józek, kiedy wczoraj tłumaczył Kasi lekcje, wprowadził ją w błąd [wyjątkowo] niechcący, ale od pewnego czasu za każdym razem, kiedy pomagał jej w lekcjach, robił to celowo.

Używając przysłówka niechcacy w nieakcentowanej, przedorzeczeniowej pozycji, zakładamy zatem, że to, co zrobił x, nie jest zwyczajnym sposobem jego postępowania. Tutaj, podobnie jak poprzednio, komponent „niechceniowy" w pozycji tematycznej oddziałuje na ogólny agentywny kontekst 
zdania, gdy tymczasem w pozycji rematycznej trafia jedynie - by tak rzec w konkretny czyn w konkretnym momencie czasowym. I mimo że ta druga sytuacja jest pod względem semantycznym prostsza, to jednak czujemy, że w jakimś sensie jest dewiacyjna: kiedy słyszymy, że x zrobił coś niechcący, raczej nie podejrzewamy, że normalnie robi on to celowo, lecz jesteśmy gotowi przyjać, że z reguły tego czegoś nie robi w ogóle, albo przynajmniej tego unika. ( $Z$ tego powodu nie jestem na przykład skłonna wierzyć mojemu synowi, jeśli po praz piąty w ciągu dziesięciu minut boleśnie kopnął pod stołem swoją siostrę, a przy tym uparcie twierdzi, że za każdym razem robił to „niechcący” i ,przez przypadek”...)

Wszystko to pokazuje, że istotnie trzeba dobrze przemyśleć problem semantycznego pierwszeństwa wśród omawianych wyrażeń, gdyż bardzo prawdopodobne, że w tym wypadku prostszy zestaw cech nie będzie wcale wyznacznikiem podstawowej jednostki. Przeciwnie - wydaje się właśnie, że swoje najbardziej specyficzne właściwości wyrażenie niechcacy ujawnia dopiero w pozycji tematycznej, która dla jednostek prymarnie rematycznych musi być jednak uznana za pozycję wtórną. Tak więc z jednej strony należałoby przyjąć, że w wyniku operacji tematyzacyjnej przysłówek „obrasta” pewnymi dodatkowymi znaczeniami, z drugiej jednak strony właśnie te „dodatkowe" znaczenia dawałyby dopiero pełną charakterystykę interesującego nas wyrażenia. ${ }^{6}$ Pod względem kolejności derywacyjnej jest zatem tak, że to pozycja tematyczna daje impuls do powstania określonych wtórnych sensów (zgodnie z wyjaśnieniami powyżej), jednak z punktu widzenia czysto synchronicznej semantyki można powiedzieć coś całkiem przeciwnego, mianowicie to, że p e w n e elementy treści przysłówka będą się właśnie n e u tra lizowały w pozycji rematycznej.

2.2. Drugi przysłówek, który chciałabym tu wykorzystać w charakterze przykładu, to przypadkiem (poświęcam mu też osobny artykuł: Duraj-Nowosielska 2013). W referacie wygłoszonym w Toruniu (w lipcu 2011 r.) postawiłam hipotezę, że przypadkiem zachowuje się jak modyfikator intencjonalności działania, tzn. że odwołuje się do kontekstu agentywnego, nawet jeśli to nie jest widoczne na powierzchni zdania. Na ten referat odpowiedział mi po-

6 Czytelników zainteresowanych szczegółami charakterystyki semantycznej przysłówka niechcacy odsyłam do cytowanej tu już małej pracy monograficznej pt. Nie przypadkiem o 'niechcacy' (w druku [a]). 
lemicznie w formie listu prof. A. Bogusławski i dwa najważniejsze przykłady, które będę dalej omawiała, pochodzą właśnie z tego źródła. Co prawda w tym miejscu moim celem nie jest obrona postawionej wówczas hipotezy (którą dalej zresztą modyfikuję), lecz pokazanie, jak interpretacja wyrażenia przypadkiem będzie się różnić w zależności od zajmowanej przez nie pozycji w zdaniu, jednak w istocie obydwa te problemy ściśle się ze sobą wiążą, dlatego pytanie o rolę intencjonalnego działania $\mathrm{w}$ zdaniach z przypadkiem będzie się w tych rozważaniach przewijało. Zakładam, że ewentualne odniesienie tego wyrażenia do pojęć agensa i agentywności miałoby charakter jakiegoś rodzaju implikacji i sytuowałoby się poza jego podstawową zawartością treściową, która wskazuje na „czystą koincydencję”, „niezależność zdarzeń” (zob. Grochowski 2009, Bogusławski 2009); por. też dyskusję na ten temat w: Duraj-Nowosielska (2013), gdzie rozważam kwestię eksplikacji przysłówka przypadkiem (w tym miejscu nie podejmuję tego tematu in extenso).

Odniesienie to może dać o sobie znać na różnych płaszczyznach. Najprostsze sytuacje interpretacyjne są oczywiście takie, kiedy zdanie wprost odwołuje się do czyjegoś działania, jak w:

(21) Janek przypadkiem strącił ręką wazon $\rightarrow$ Janek nie chciał strącić ręką wazonu.

Skąd się bierze ta implikacja? A przede wszystkim - o jakich niezależnych zdarzeniach jest mowa w tym przykładzie? Zgodnie z interpretacją tego typu zdań, zaproponowaną we wspomnianym artykule (Duraj-Nowosielska 2013), samo strącenie ręką wazonu nie jest niezależne od czegokolwiek, lecz jest $\mathrm{s} \mathrm{k}$ u t k i e m dwóch pośrednio wskazanych w zdaniu zdarzeń / stanów rzeczy: tego, co zrobił Janek (machnął ręką) (p), oraz tego, że wazon stał w takim a nie innym miejscu (q). Dopiero o p i q możemy powiedzieć, że są od siebie niezależne, inaczej mówiąc: p zaszłoby, gdyby q nie miało miejsca (oraz q miałoby miejsce, gdyby nie zaszło p) ${ }^{7}$.

Z kolei ich zależność, tj. nieprzypadkowość wystąpienia jednego zdarzenia w odniesieniu do drugiego wyznaczona by była właśnie w relacji intencjonalnej: Janek machnął ręką w określony sposób, ponieważ w określonym

7 Por. w związku z tym wyrażenie wskutek zbiegu okoliczności, podawane w słownikach jako ekwiwalent przypadkiem, które idealnie odpowiada tego rodzaju przykładom (choć niekoniecznie innym). 
miejscu stał wazon (a on chciał go strącić), tj. nie machnąłby ręką tak-a-tak, gdyby wazon tam nie stał (przy pozostałych okolicznościach bez zmian). Tym zatem, co w zdaniu:

(22) Jan nie przypadkiem strącił ręką wazon

scala całość sytuacji, definiując zależność wskazanych pośrednio zdarzeń, jest intencja zawarta w działaniu Jana, nakierowanym na strącenie wazonu stojącego w określonym miejscu. Gwoli ścisłości, zdanie (22) może też wyrażać zależność odwrotną, tj. zależność q od p w relacji celowej:

(22a) Jan nie przypadkiem strącił ręką ten wazon - to Kasia celowo go postawiła w takim miejscu, żeby można go było łatwo potrącić; chciała się po prostu pozbyć tego paskudztwa z domu -

mimo że Jan działał tutaj nieświadomie, wpasował się ze swoim czynem w sytuację w jakiś sposób chcianą (i zaaranżowaną) przez Kasię; ważne, że w zdaniu w ogóle pojawia się ,implikacja intencjonalna” odniesiona do możliwości strącenia wazonu. Por. (22a) z:

(22b) *Jan nie przypadkiem strącił ręką ten wazon - wczoraj Kasia go w tym miejscu postawiła, bo chciała ozdobić w ten sposób przedpokój.

W sytuacji odwrotnej, określonej w przykładzie (22), przysłówek przypadkiem, wykluczając zależność dwóch wskazanych pośrednio zdarzeń, wyklucza więc automatycznie intencjonalne działanie zarówno Jana, jak i innych ewentualnych agensów, które mogłyby mieć wpływ na dane zdarzenie. W tym drugim wypadku trzeba zatem szukać odniesienia do intencjonalności głębiej, pod powierzchniq zdania. Podobną sytuację wyraża też na przykład zdanie (rozważane w: Duraj-Nowosielska 2013, a zarazem nawiązujące do przykładu podanego przez Grochowskiego 2009):

(23) Kiedy Kasia przechodziła przez podwórko, przypadkiem spadła jej na głowę cegła,

które implikuje, że nikt nie zrzucił jej tej cegły na głowę celowo; por.: 
(23a) *Kiedy Kasia przechodziła przez podwórko, spadła jej przypadkiem na głowę cegła - okazało się, że rzucił nią w Kasię dla żartu Janek. Vs:

(23b) Kiedy Kasia przechodziła przez podwórko, spadła jej przypadkiem na głowę cegła - okazało się, że zrzucili ją nieostrożni robotnicy pracujący na dachu.

Zob. także np.:

(24) Dowiedziałam się przypadkiem, że Kasia zamierza wyjechać - zobaczyłam, jak pakuje walizki. / Kasia sama wygadała się o tym. Vs:

(24a) *Dowiedziałam się przypadkiem, że Kasia zamierza wyjechać sama mnie wczoraj do siebie zaprosiła i mi o tym powiedziała.

Poza takimi sytuacjami, gdzie odniesienie do agensów i agentywności jest stosunkowo łatwo dostępne myślowo, można jeszcze wskazać konteksty, w których takiego odniesienia nie sposób wytropić, tj. konteksty z góry eliminujące możliwość interwencji podmiotów osobowych. Tego typu sytuacje, w istocie zdecydowanie rzadsze, niżby mogło się wydawać, zakładają konieczność postawienia przypadkiem pod akcentem, o czym będę mówiła dalej; przysłówek w pozycji neutralnej natomiast zdaje się wykluczać tego rodzaju konteksty sytuacyjne.

2.2.1. W polemicznej odpowiedzi na wspomniany referat A. Bogusławski podaje między innymi pewien przykład, który można by było zawrzeć w zdaniu:

(25) Jan, znany z niezdarności i z tego, że nigdy w nic nie trafia, rzucił pewnego dnia cegłą w Anię i tym razem zupełnie przypadkiem ją trafił.

Tego rodzaju sytuacja, niewykluczająca, jak widać, użycia słowa przypadkiem, mogłaby świadczyć przeciwko tezie, że przysłówek ten implikuje brak intencjonalnego działania. Przypatrzmy się zatem temu przykładowi bliżej.

Po pierwsze, przysłówek w (25) musi stać pod akcentem, w przeciwnym razie odrzucimy to zdanie jako nieakceptowalne, por.: 
(25a) Jan, znany z niezdarności i z tego, że nigdy w nic nie trafia, rzucił pewnego dnia cegłą w Anię i tym razem zupełnie przypadkiem ją trafił. Vs:

(25b) ? Jan rzucił cegłą w Anię, celując w jej ramię, i przypadkiem ją $\mathrm{w}$ to ramię trafil - co jest o tyle dziwne, że jest niezdarny i nigdy w nic nie trafia.

Nieakceptowalne jest także zdanie podobne, z odwróconą diatezą:

(26) ? Ania została pewnego dnia przypadkiem trafiona cegłą, którą rzucił w nią Jan, znany z niezdarności i z tego, że nigdy w nic nie trafia.

Można zatem tak powiedzieć, ale tylko wówczas, gdy usiłowania Jana w połączeniu z jego niezdarnością będą tworzyły wyjściowy kontekst, z którym następnie jest kontrastowana niespodziewana celność rzutu. Ponieważ w tego rodzaju zdaniach chodziłoby właśnie o wyraźny kontrast z podstawowym kontekstem, przysłówek musi zostać zaakcentowany:

(25c) Jan rzucił cegłą w Anię, celując w jej ramię, ale trafił ją w to ramię przypadkiem - normalnie jest strasznie niezdarny i nigdy w nic nie trafia.

Zwróćmy uwagę, że to samo dotyczy wszystkich czasowników, w których znaczeniu istnieje jakby ,wolna przestrzeń” pomiędzy działaniami kontrolowanymi przez agensa a osiągniętym przez niego skutkiem (tj. czasowników nazywanych przez rosyjskich semantyków czasownikami „,niepełnej kontroli”, por. np. Šatunovskij 1989). Ta przestrzeń to właśnie przestrzeń możliwego „przypadku”, swoista luka w intencjonalnym działaniu. Czasowniki ,pełnej kontroli" natomiast w ogóle wykluczają przypadkiem, por.:

(27) Bardzo się napracował, ale sukces odniósł jednak przypadkiem. Vs:

(28) *Napracował się zupełnie przypadkiem.

(29) Długo się namyślał, ale ta idea wpadła mu do głowy zupełnie przypadkiem. Vs:

(30) *Długo się namyślał, ale robił to przypadkiem.

W zdaniach akceptowalnych, takich jak (27) i (29), przysłówek - jak zaznaczałam - musi stać pod akcentem, dlatego właśnie, że chodzi w nich 
o skontrastowanie jakiegoś jego istotnego składnika semantycznego z zadanym kontekstem; por::

(27a) *Bardzo się napracował, ale/ i przypadkiem odniósł sukces.

(29a) *Długo się namyślał, ale/ i ta idea przypadkiem wpadła mu do głowy.

Zatem kiedy mówię, że Jan dużo pracował, ale sukces odniósł przypadkiem, mówię tym samym, że jego intencjonalne działanie, mimo że miało miejsce i mogło być dokładnie wycelowane na osiągnięcie sukcesu, nie miało jednak (większego) wpływu na osiągnięty sukces, a przynajmniej nie było jego bezpośrednią przyczyną. W tym sensie jak najbardziej wykluczona jest tu intencjonalność jako przyczyna osiągniętego skutku. (To samo można powiedzieć o wszystkich przywołanych wyżej przykładach.)

Z drugiej strony, w kontekstach nienacechowanych jest tak, że jeśli ktoś coś robi z jakimś celem i ów cel dochodzi do skutku, przyjmujemy niejako automatycznie, że owo robienie jest główną przyczyną zdarzenia skutkowego (co oczywiście nie oznacza, że nie złożyły się na nie także i inne okoliczności) - i taką właśnie sytuację wyklucza słowo przypadkiem. Nie przeczą temu konteksty „specjalne”, w których ktoś coś robi, lecz nadawca podkreśla, że skutek jest $\mathrm{w}$ jakimś istotnym sensie niezależny od tego robienia i że najbardziej zaważyły tu właśnie owe ,inne okoliczności”, jak w (25) - te ostatnie są kontekstami inherentnie kontrastywnymi, wymagającymi zaakcentowania odpowiedniego przysłówka.

Jak widać, jest to sytuacja podobna do tego, o czym była mowa w związku z przysłówkiem niechcacy: tutaj także wyrażenie rematyczne „celuje” dokładnie w pewne konkretne zdarzenie w konkretnym momencie czasu, wykluczając sprawstwo podmiotu osobowego w y nikające z jego określonej intencji przekładającej się na określone działanie (jednak bez przesądzenia braku jakichkolwiek działań i intencji skierowanych na dany stan rzeczy), gdy tymczasem w pozycji tematycznej przypadkiem oddziałuje na cały kontekst, w o góle wykluczając działanie z określoną intencją.

2.2.2. Drugi kontrprzykład podany przez A. Bogusławskiego dotyczy sytuacji - interesujących nas tu w sposób szczególny - w których w ogóle nie może być mowy o jakimkolwiek działaniu, tj. sytuacji umieszczonych 
w kontekstach ,nieziemskich”. I tak, o pewnej planecie z galaktyki Alfa Centauri, podobnej do naszej planety, można powiedzieć:

(31) Odległość planety $\alpha$ od jej słońca przypadkiem jest identyczna z odległością Ziemi od Słońca.

Trzeba podkreślić, że tego rodzaju przykłady są bardzo trudne do interpretacji, głównie z tego powodu, że na problem własności semantycznych przypadkiem (nie przypadkiem) nakłada się jeszcze problem owego kosmicznego kontekstu: ponieważ przeciętny użytkownik języka niewiele może o nim powiedzieć, nie wiadomo właściwie, jakie zastosowanie tak naprawdę mają do tego kontekstu interesujące nas przysłówki. W rezultacie trudno ustalić, co się złożyło na ewentualną nieakceptowalność zdania, tj. czy były to własności semantyczne przysłówka, czy może w grę wchodziła nieustabilizowana wiedza o kontekście; dwóch informatorów może się bowiem nie zgodzić co do akceptowalności / nieakceptowalności jakiegoś zdania przy jednoczesnym uznaniu tych samych własności przysłówka. Skoro jest to kwestia naszych potocznych wyobrażeń (dla psalmisty na przykład kosmiczny kontekst nie eliminuje działania), trudno traktować przykłady takie jak (31) jako konteksty diagnostyczne w celu ustalenia własności semantycznych odpowiednich wyrażeń; kontekst diagnostyczny musi być oczywisty, w przeciwnym razie nie będziemy w stanie niczego pewnego na jego podstawie ustalić.

Odwoływanie się do wiedzy naukowej w rozważaniach semantycznych byłoby na pewno nieuprawnione, a skoro tak, zdam się na własną intuicję w tym względzie (intuicję z gatunku commonsense philosophy) i powiem, że o zdarzeniach z poziomu "kosmicznego" w istocie nie da się sensownie powiedzieć, że zaszły „przypadkiem”. Ściślej mówiąc - nie da się tego powiedzieć w sensie absolutnym, tj. uwzględniając wszelkie możliwe okoliczności zdarzeń, tak jak to ma miejsce w ,nagich” asercjach, w których nadawca - by odwołać się do słów A. Bogusławskiego (2009) - „aspiruje do wszechwiedzy". W świecie z góry wykluczającym działanie jakichkolwiek agensów (a na taki ma wskazywać przykład [31]) nie spodziewamy się właśnie ,przypadku”, oczekujemy raczej w s p ół z a le ż n o ś c i zdarzeń. $Z$ tego powodu trudno uznać na przykład akceptowalność zdania (z akcentem na przypadkiem, bo takie sytuacje rozważymy w pierwszej kolejności): 
(32) ? Kometa $\beta$, pędząc $w$ przestworzach z prędkością p, przypadkiem zderzyła się z planetą $\gamma$. Por.:

(32a) ? Uwzględniając wszelkie możliwe okoliczności, kometa $\beta$, pędząc $\mathrm{w}$ przestworzach z prędkością $\mathrm{p}$, zderzyła się z planetą $\gamma$ przypadkiem ${ }^{8}$.

Czy możemy sobie wyobrazić Wszechwiedzącego, który wypowiada zdanie (32) bądź (32a)? (Z drugiej strony, „wszechwiedzący” punkt widzenia nie wyklucza powiedzenia: Uwzględniajac wszelkie okoliczności, Jan stracit ręka ten wazon przypadkiem - w żadnym razie nie chciat tego zrobić; albo: Uwzględniajac wszelkie okoliczności, Janek spotkat Jankę na uniwersytecie przypadkiem - nie poszedt tam specjalnie po to, żeby ja spotkać9). Oczywiście, znak ,?" dotyczy przykładu (32) (a także innych podobnych) o tyle, o ile założymy, że w danym momencie żaden agens nie ma wpływu na konfigurację gwiazd i planet, co, jak powiedziałam, w naszym świecie jest kwestią u-(bądź wy-)znaniową.

Przy takim założeniu, na analogicznej zasadzie nie można powiedzieć na serio (tj. ,z aspiracją do wszechwiedzy”, jak to się dzieje w zwykłych asercjach), kładąc przycisk zdaniowy na przypadkiem:

${ }^{8}$ Co więcej, jeśli nie jest możliwe wypowiedzenie takich zdań, orzeczenie nieprzypadkowości analogicznych zdarzeń w zasadzie także traci swoje podstawy. Normalnie nie powiedzielibyśmy: (?) Kometa $\beta$, pędzqc $w$ przestworzach z prędkościq p, nie przypadkiem zderzyla się z planeta $\gamma$. O tym, co z z ało ż e $\mathrm{n}$ i a nie może być przypadkowe, nie ma sensu normalnie orzekać, że jest nieprzypadkowe, tak jak - by nawiązać do poprzedniego przysłówka - o tym, czego nie możemy chcieć (tzn. chcieć na serio, z możliwością spowodowania tego stanu rzeczy), nie orzekniemy, że zrobiliśmy to niechcacy (por. ? Janek niechcqcy spadł ze schodów. Vs: Janek niechcacy zrzucit Krzyśka ze schodów). Inna sprawa, że hipotetycznie można poddać w wątpliwość same założenia funkcjonowania świata bez agensów - wówczas w jakimś sensie uzasadnione byłyby ogólne stwierdzenia tego rodzaju jako odpowiedź na zadaną alternatywę (Nic nie dzieje się przypadkiem itp.) - ale to są stwierdzenia zakładające Wittgensteinowski ,view from nowhere", wypowiedziane ,z zewnątrz" (metafizyczne) i jako takie w istocie n i e m o żliw e do powiedzenia w sensie dosłownym.

$9 \mathrm{Tj}$. nie wyklucza tego pod warunkiem, że założymy respektowanie przez owego „Wszechwiedzącego” (i „Wszechmocnego”) wolnej woli istot stworzonych na jego obraz i podobieństwo. „Bóg deterministów” nie robiłby różnicy pomiędzy działaniem osobowym a innymi zdarzeniami zachodzącymi w świecie - wszystkie one na równi podlegałyby związkom kauzalnym. 
(33) ? Odległość Ziemi od Słońca (planety $\alpha$ od jej słońca) przypadkiem wynosi $150 \mathrm{mln} \mathrm{km}$. / To przypadek, że odległość Ziemi od Słońca (planety $\alpha$ od jej słońca) wynosi $150 \mathrm{mln} \mathrm{km}$.

Tutaj ciąg jakichś zdarzeń, o których nie sposób powiedzieć, że były przypadkowe, doprowadził do tego, że odległość Ziemi od Słońca (planety $\alpha$ od jej słońca) wynosi dokładnie tyle, ile wynosi... Dalej trzeba by się spytać, w jakim sensie można orzec, że zbieżność tych skądinąd nieprzypadkowych stanów rzeczy jest przypadkowa, tj. że chodzi o ich „czystą koincydencję”? Inaczej mówiąc - w jakim sensie jest wymawialne zdanie (31)?

Mając dwa stany rzeczy (odległości planet od ich słońc), które jako takie są uznane za nieprzypadkowe, czy można rzeczywiście serio powiedzieć w świecie pozbawionym możliwości interwencji ze strony agensów - że ich ide nt yc zność jest przypadkowa? Myślę, że z ,absolutnego” punktu widzenia jest to rzecz co najmniej dyskusyjna... Oczywiście, w (31), podobnie jak w (32) czy (32a), zawsze jest możliwe ograniczenie asercji do punktu widzenia podmiotu: nie mając wszystkich danych, zaznaczamy, że z naszego punktu widzenia to czysty przypadek; asercje „,bez ogródek” zdają się jednak wykluczać taką interpretację. Zdanie (31) niesie więc ze sobą - twierdziłabym - ukryte zawężenie odniesienia, relatywizujące wypowiedź do „niewszechwiedzącego" punktu widzenia:

(31a) Wziąwszy pod uwagę dane, jakimi dysponujemy, odległość Ziemi od Słońca jest przypadkiem identyczna z odległością planety $\alpha$ od jej słońca -

tzn. wśród zdarzeń, które ogarniamy naszą wiedzą, nie ma takich, które zdołałyby powiązać kauzalnie te dwa stany rzeczy.

Te przykłady dotyczyły sytuacji, kiedy interwencja podmiotu osobowego teoretycznie nie była możliwa. Ale zwróćmy uwagę, co się dzieje, jeżeli tylko zamienimy (31) na przykład podobny, tylko osadzony w ziemskich warunkach:

(34) [Marek i Wacek rozbili obozowiska nad jeziorami.] Odległość pomiędzy jeziorem, nad którym koczował Marek, a jeziorem, nad którym ko- 
czował Wacek, jest przypadkiem identyczna jak odległość pomiędzy ich domami w Warszawie.

Mimo że z założenia jeziora, podobnie jak planety, nie poddają się manipulacji ze strony agensów, w tym zdaniu od razu pojawia się interpretacja, że Marek i Wacek nie planowali takiej zbieżności, nie rozbijali obozów specjalnie nad tymi jeziorami.

Wniosek nasuwa się tutaj taki, że zdania z zaakcentowanym przysłówkiem albo będą się bezpośrednio lub pośrednio odwoływały do działań jakichś agensów, o ile takie będą d o s tę p n e w kontekście interpretacyjnym, albo będą ograniczały w inny sposób ów dostępny kontekst (przykrawając go - by tak rzec - na miarę człowieka), jeśli interpretacja agentywna będzie nieosiągalna. W każdym razie obecność podmiotów osobowych $\mathrm{w}$ zasięgu interpretacji przesądza by default o ich zaangażowaniu (w przypadkiem - przez wskazanie właśnie na brak ich zaangażowania ,intencjonalnego", w nie przypadkiem - odwrotnie); i jest tak mimo tego, że w podstawowej zawartości treściowej pojęcia przypadku nie ma przecież mowy o żadnych agensach, a jedynie o jakimś zdarzeniu p niezależnym od jakichś innych zdarzeń. Sugerowałabym wstępnie, żeby w owej „nieintencjonalności” (wyrażonej w taki czy inny sposób) widzieć w związku z tym jakiś rodzaj regularnej implikacji pragmatycznej wyrażenia przypadkiem, z tego względu, że odniesienie do agensów i ich działań mimo wszystko zależy od ich dostępności kontekstowej.

Można by się tu pokusić o komentarz, że agensy mają w pojęciu przypadkowości bardzo szczególną, podwójną rolę do spełnienia. Proponuję na to patrzeć tak, że z jednej strony u możliw i aj ą one w ogóle przypadkowość, w tym sensie, że swoim ex definitione wolnym działaniem rozrywają raz po raz naturalnie rozwijający się ciąg przyczyn i skutków, a tym samym przekreślają możliwość ostatecznego skalkulowania skutków na podstawie poprzedzających je zdarzeń (i nie jest to tylko kwestia naszej ograniczonej wiedzy, bo rzecz dotyczy, co podkreślałam, wiedzy obiektywnej - wiedzy „wszechwiedzącego").

Z drugiej strony to właśnie działania najwyraźniej są postrzegane jako podstawowe „spoiwo” dla zdarzeń, skoro pojęcie przypadku (zaprzeczające przyczynowo-skutkowemu zespoleniu wskazanych w zdaniu stanów rzeczy) w y bi e r a z kontekstu - można by powiedzieć - pierwszego dostępnego 
agensa, podmiot gotow y do działania, by ostatecznie zaprzeczyć interwencji z jego strony; ${ }^{10}$ innymi słowy, orzekając przypadkowość zdarzeń, odwołujemy się do agensa (wyrażonego w zdaniu bądź domyślnego), gotowego połączyć w działaniu jakieś wskazane stany rzeczy, a następnie blokujemy nasuwające się w ten sposób połączenie. Interpretacja „,czysto koincydentalna”, bez domieszki agentywnościowej, pojawiałaby się dopiero w momencie, gdy te poszukiwania skończą się niepowodzeniem.

Zostawiając ten wątek, powróćmy do naszych przykładów. Analizowane dotychczas zdania - przypomnę - dotyczyły akcentuacji rematyzującej przysłówek. Teraz sprawdźmy, jak można zinterpretować zdanie (31) z przyciskiem zdaniowym tylko na orzeczeniu:

(31b) Odległość planety $\alpha$ od jej słońca przypadkiem jest identyczna z odległością Ziemi od Słońca -

otóż tak można powiedzieć tylko wtedy, jeśli zestawimy właściwości naszej planety z właściwościami jakiejś uprzednio wybranej przez nas planety $\alpha$. Gdybyśmy szukali planety o identycznej charakterystyce, nie moglibyśmy powiedzieć:

(35) *Przez lata szukaliśmy planety, której odległość od najbliższej gwiazdy byłaby bardzo zbliżona do odległości Ziemi od Słońca, i w końcu znaleźliśmy planetę, która przypadkiem ma takie właściwości.

Zdanie (31b) jest zatem akceptowalne jedynie w sytuacji, gdy bierzemy pod uwagę naszq aktywność jako obserwatorów planet $\alpha$ i Ziemi. Przypadek dotyczy w istocie w y b or u, samego wskazania, a nie charakterystyki planet. Trudno mi w tym momencie rozstrzygnąć, czy przypadkiem spełnia tu rolę wyrażenia metapredykatywnego (jak np. w Masz przypadkiem zapatki?, zob. na ten temat Grochowski 2009, Bogusławski 2009), ale na pewno w tego rodzaju kontekstach, tj. z jednej strony przez swój układ akcentowy przesądzających o tematyczności przysłówka, a z drugiej eliminujących ze swej natury kontekst działaniowy, wyrażenie to traci swoje „zwykłe” własności

10 Por. w tym kontekście słowa A. Bogusławskiego (2009:149): „Nie jakaś wszechogarniająca przy-czyn-a wszystko wiąże. Wszystko w ostateczności wiążą czyny - stwórcze i zwykłe, właściwe organizmom, ludzkim i innym (...)." 
przysłówkowe. Co ważne, tego problemu nie będzie już w zdaniach $\mathrm{z}$,dostępnymi” agensami:

(34a) Odległość pomiędzy jeziorem, nad którym koczował Marek, a jeziorem, nad którym koczował Wacek, przypadkiem jest identyczna jak odległość pomiędzy ich domami w Warszawie,

gdyż przypadkiem niejako w zwykły sposób wyklucza w nich intencjonalne działanie, zachowując się jak modyfikator intencjonalnościowy. Z drugiej strony, zdania takie jak (32), uznane za niekaceptowalne, nie mają również odpowiedników z nieakcentowanym przysłówkiem, por::

(32b) ? Kometa $\beta$, pędząc $\mathrm{w}$ przestworzach z prędkością $\mathrm{p}$, przypadkiem zderzyla się z planetą $\gamma$,

po prostu dlatego, że nie podsuwają one żadnej interpretacji analogicznej do powyższych.

Można więc powiedzieć, że zdania z przysłówkiem nieakcentowanym jeszcze bardziej ciążą ku interpretacji agentywnościowej niż zdania z przysłówkiem pod akcentem, o tyle, o ile te ostatnie dopuszczają mimo wszystko konteksty bez agensów „w pogotowiu”. Tematyzowane przypadkiem natomiast, oprócz tego, że „,celuje” w konkretne zdarzenia, orzekając wprost i po prostu ich niezależność przyczynowo-skutkową (tak jak to robi przypadkiem rematyczne), obejmuje jeszcze dodatkowo swym zasięgiem szerokie treści kontekstowe podsuwane przez zdanie, począwszy od „testowania otoczenia” pod kątem ewentualnego celowego sprawstwa (por. [34a]), aż po uwzględnienie samej sytuacji mówienia (w tym ostatnim zbliżając się do wyrażenia metapredykatywnego, [31b]).

Tak więc trzeba podsumować, że - pominąwszy te w istocie rzadkie sytuacje, w których kontekst interpretacyjny zdania wyklucza całkowicie aktywność podmiotów osobowych - typowo zdania z przypadkiem, wskazujące w swych dictach na „niezależność zdarzeń”, przejawiają zadziwiające wręcz ciążenie ku interpretacjom agentywnopochodnym. Jest tak właściwie niezależnie od rozkładu akcentów w zdaniu, aczkolwiek w sposób szczególny dotyczy to przysłówków w pozycji tematycznej, które przy braku dostępnej 
interpretacji agentywnej tracą swoje przysłówkowe właściwości i zaczynają funkcjonować na poziomie metapredykatywnym, z odniesieniem do samego działania mownego nadawcy.

Na marginesie wątku intonacyjnego, a kończąc wątek agentywnościowy, powtórzę, że owo ciążenie może się brać z postulowanego tu podstawowego odniesienia pojęcia przypadku do sfery agentywnej: jak powiedziałam, odniesienie to polega na tym, że z obiektywnego punktu widzenia przypadek zdaje się w ogóle możliwy dzięki obecności działań, czynów, ponieważ to one raz po raz rozrywają - dzięki niezbywalnej wolności agensów - „naturalny” łańcuch przyczynowo-skutkowy zdarzeń. Jako drugi decydujący tu czynnik wskazałam to, że agensy są postrzegane jako „ogniwa”, które w najbardziej ścisły, najbardziej niezawodny, a mimo to zasadniczo wolny sposób łączą w swym działaniu określone stany rzeczy. W pojęciu przypadku, rozdzielającym w sensie przyczynowo-skutkowym zdarzenia, które w jakimś innym sensie się ze sobą stykają (najpewniej w czasie i/lub przestrzeni), bylibyśmy zatem zainteresowani przede wszystkim wyeliminowaniem właśnie tego mocnego ogniwa, jakim jest ewentualne sprawstwo podmiotów działań ${ }^{11}$.

Podsumowując całość, należałoby z kolei podkreślić rzecz następującą: jak wynika z moich wstępnych obserwacji, wszystkie przysłówki z grupy „modyfikatorów intencjonalnościowych” będą wykazywały jakieś rozbieżności interpretacyjne w zależności od zajmowanej pozycji w zdaniu. Rozbieżności te będą bardziej lub mniej poważne, na przykład w implikacji „habitualnej” przysłówka niechcacy (,x na ogół tego nie robi”) można widzieć pewien szczegół interpretacyjny, ale za taki trudno już będzie uznać implikację ,,agentywną” przysłówka przypadkiem, w ogóle przesądzającą o zaliczeniu go do tej klasy wyrażeń; nawet zresztą te detale mają swoją rolę do odegrania, gdyż bez nich charakterystyka tych wyrażeń może się okazać co najmniej niekompletna. Tak czy inaczej, przysłówki tego rodzaju przejawiają dużą wrażliwość na kontekst tematyczno-rematyczny, w jakim występują, dlatego ich poszczególne składniki treściowe zawsze powinny być pod tym katem badane. Nie zaryzykowałabym stwierdzenia, że mamy tu do czynienia z różnymi jednostkami językowymi (choć semantyka zna przecież i ta-

11 Problem interpretacji agentywnej przysłówka przypadkiem rozwijam we wspomnianym artykule $O$ (tajemniczej) roli intencjonalnego działania $w$ zdaniach z przysłówkiem 'przypadkiem' (w druku [b]). 
kie przypadki, np. ktoś podejrzewa, że_i ktoś podejrzewa, że_, gdzie tylko to drugie wyrażenie jest faktywne, por. Danielewiczowa 2002: 284-285), ale te różnice, które się pojawiają przy zmianie pozycji w ramach dictum, z pewnością nie są semantycznie zaniedbywalne.

Dwie wyłaniające się tu kwestie teoretyczne, o jakich wspominałam, to po pierwsze - który zestaw cech należałoby traktować jako wyjściowy, a po drugie - jakie ewentualne regularności (być może operacyjne w sensie Bogusławskiego 1978) można by było wytropić przy przejściu od jednego semantycznego zestawu do drugiego. Szczególny problem interpretacyjny, z jakim zostajemy przy tej okazji skonfrontowani, polega na tym, że z jednej strony za reprezentatywne powinny być uznane przysłówki w neutralnej pozycji tematycznej, z drugiej jednak strony ta pozycja w porównaniu z pozycją rematyczną wyraźnie generuje pewne sensy nadwyżkowe. Niewykluczone, że w końcowym opisie trzeba będzie przyjać jako wyjściowy zestaw cech charakteryzujących przysłówki rematyczne, ale reprezentatywne dla klasy byłyby mimo wszystko wyrażenia wtórne, tematyczne (co być może byłoby specyfiką tego rodzaju wyrażeń.) Oczywiście to, o jakie szczegółowe operacje na modyfikatorach intencjonalnościowych może tu chodzić, będziemy mogli poznać dopiero po dokładniejszym przebadaniu tej klasy.

\section{Bibliografia}

Austin J., 1977, Jestem niewinny, Znak 29, s. 667-696.

BogusŁawski A., 1977, Problems of the Thematic-Rhematic Structure of Sentences, Warszawa: PWN.

Bogustawski A., 1978, Towards an Operational Grammar, w: Jerzy Pelc (red.), Studia Semiotyczne VIII, Wrocław-Warszawa-Kraków: Zakład Narodowy im. Ossolińskich, s. 29-90.

BogusŁawsKi A., 1999, Inherently thematic or rhematic units of language, w: E. Hajičova et al. (red.), Travaux du Circle Linguistique de Prague 3, Amsterdam, s. 211-224.

BogusŁawski A., 2009, Dwa przykłady analizy semantycznej z wykorzystaniem materiału negatywnego, w: idem, Myśli o gwiazdce i regule, Warszawa: BEL Studio, s. 137-150.

Danielewiczowa M., 2002, Wiedza i niewiedza. Studium polskich czasowników epistemicznych. Warszawa: Wyd. Uniwersytetu Warszawskiego. 
Duraj-Nowosielska I., 2007, 'Robić coś' $i$ 'coś powodować' - opozycja agentywności i kauzatywności w języku polskim, Warszawa: Wydział Polonistyki UW.

Duraj-Nowosielska I., 2011, Co można zrobić niechcący? (Rekonesans)", Prace Filologiczne LXII, s. 105-119.

Duraj-Nowosielska I., 2013, O tym, gdzie szukać 'przypadku' w zdaniach z przypadkiem i o kilku innych własnościach tego przysłówka, w: A. Kozłowska i A. Świątek (red.), Znaczenie - tekst-kultura. Prace ofiarowane Profesor Elżbiecie Janus, Warszawa: Wyd. UKSW.

Duraj-Nowosielska I., w druku [a], Nie przypadkiem o niechcący. Szkic semantyczny, Warszawa: Wyd. UKSW.

Duraj-Nowosielska I., w druku [b], O (tajemniczej) roli intencjonalnego działania w zdaniach z przysłówkiem przypadkiem.

Grochowski M., 2009, Opozycja składniowa i semantyczna jednostek o postaci 'przypadkiem', w: G. Dąbkowski, D. Lewandowska-Jaros (red.), Polszczyzno moja... Księga jubileuszowa z okazji 40-lecia pracy naukowej i dydaktycznej Profesora Jerzego Bralczyka, Warszawa: ASPRA-JR, s.77-93.

INGARDEN R., 1987, Ksiqżeczka o człowieku, Kraków: Wydawnictwo Literackie.

ŠAtunovskiJ I. B., 1989, Propozyicional'nye ustanovki: volja i želanie, w: N.D. Arutjunova (red.), Logičeskij analiz języka: problemy intensional'nych i pragmatičeskich kontekstov, Moskwa, s. 155-185.

Talmy L., 1976, Semantic Causative Types, w: M. Shibatani (red.), Syntax and Semantics 6, New York: Academic Press, s. 43-116.

\section{Remarks on the Influence of Sentence Stress on the Interpretation of Adverbs - 'Intentionality Modifiers' (A case study of niechcacy 'unwillingly' and przypadkiem 'accidentally')}

( s u m m a r y)

In the article I consider the problem of sentence stress and its influence on the semantics of the adverbs modifying information on the intentionality of actions, i.e. expressions such as niechcacy 'unwillingly', nieświadomie 'unconsciously', przypadkiem 'accidentally', celowo 'on purpose', specjalnie 'intentionally' etc., with special attention paid to the two expressions from this class - niechcacy and przypadkiem. I try to demonstrate how their interpretation may differ according to the position they take in the sentence structure. I assume that these units of language - as they are adverbs - belong primarily to the dictum of the sentence, which means that one should take the rhematic position as basic in the explication; all the differences that result from moving them to the thematic dictum should be then interpreted as secondary (as the effect of thematizing). 
Yet, there appears to be a special methodological problem in the interpretation of this type of expressions: it lies in the fact that the rhematic position within the sentence structure cannot be accepted as their neutral position, as it always points to a particular situational context and presupposes the operation of the so called explicit theme selection. For example, in the sentence Jan podarl gazete / niechcacy 'Jan tore the paper / unwillingly' the speaker says about the fact that Jan tore the paper that he did it unwillingly. In the article I try to show that the neutral position within the sentence dictum is the thematic position, as in the sentence (taken in isolation) Jan niechcacy podart gazete 'Jan unwillingly tore the paper' (cf. Jan specjalnie podart gazete 'Jan intentionally tore the paper'. Vs: ? Jan specjalnie podarl gazetę 'Jan intentionally tore the paper').

What is more, although the thematic position triggers some "additional" senses as compared with the rhematic position, one cannot say that in the semantics of the expressions in question these are "extra senses" supplementing some other "basic senses". Contrary to that, it appears that it is in this position (and not - as could be expected - in the rhematic position) that such adverbs demonstrate their most characteristic features (which could be specific of this class). In that case one could assume that the initial set of semantic features (in the sense of derivational order) is the set tested in the rhematic position, and yet representative for a given unit would be the set of features verified in the "secondary" position, i.e. thematic one. The issues touched upon in the article are further developed in the author's monograph Nie przypadkiem $o$ 'niechcacy' and in the article $O$ (tajemniczej) roli intencjonalnego dziatania $w z d a$ niach z przystówkiem 'przypadkiem'. 